\title{
Letting go of Managing? Struggles over Managerial Roles in Collaborative Governance
}

I Mie Plotnikof'

PhD, research fellow, Department of Organization, Copenhagen Business School, Denmark

\begin{abstract}
This article discusses the role of the manager in collaborative governance studies. These studies identify a new managerial role as facilitator of stakeholder collaboration when pursuing public policy and service innovation. But the complications of role changes are underexplored; hence this article addresses the emerging challenges. Drawing on organizational discourse studies, it theorizes and analyzes managers' positioning during collaborative governance practices in cases from the Danish daycare area. The findings demonstrate how public managers construct old and new roles related to various public management discourses, and their struggles to change accordingly. However, the findings also show how managers empower their new role and gain agency to steer collaborative outcomes. Thereby the article unpacks the challenges of becoming a facilitating manager alongside other roles: the struggles of identity and agency constitutive to particular ways of managing, as well as struggles over multiple roles. It suggests paying greater attention to constitutive aspects of changing roles to understand the managerial challenges and effects implied through emerging public management discourses.
\end{abstract}

\section{KEY WORDS}

Collaborative governance / managerial roles / new public management / new public governance / organizational discourse / positioning

DOI

10.19154/njwls.v6il.4888

\section{Introduction}

urrently, collaborative governance practices are emerging in the public sector to involve stakeholders in dealing with complex issues such as welfare policy and service innovation (Ansell \& Gash, 2008; Bryson, Crosby \& Stone, 2015). Scholars thus stress collaboration across public, private, and nonprofit organizations as a new critical tendency (Christensen \& Lægreid, 2011; Osborne, 2009). This is diagnosed as part of the new public governance (NPG) and contrasted to, but working alongside other discourses such as new public management (NPM). It is a 'post-NPM 'governance' paradigm which places far more emphasis on partnership, networking and lateral modes of organizing than the vertical 'command and control' forms typical of the NPM paradigm' (Ferlie, Hartley \& Martin, 2003: 10). But stakes are high when collaboration becomes a

\footnotetext{
${ }^{1}$ Contact details: Mie Plotnikof, Department of Organization, CBS, Kilevej 14, 2000 Frederiksberg, Denmark. Email: mp.ioa@cbs.dk.
} 
means of governance. The prospects of co-creating solutions are appealing to democratic ideals; however, the risk of failure-due to, for example, conflict of interests or ineffectiveness-is a considerable challenge (Vangen \& Winchester, 2013). As such, NPG discourses and collaborative governance initiatives demand changes in the working lives of public management actors, who are to deal with collaboration and its outcome (Hartley, 2005).

In this regard, the manager is given a lot of attention. Despite differences, many studies stress the complexity of collaborative governance, which they argue demand a new role of managers (O'Leary \& Vij, 2012). Some theorize the task of managing collaborative governance in concepts of diversity inclusion, capacity-building, and facilitation (Ansell \& Torfing, 2014; Johnston, Hicks, Nan \& Auer, 2010; Silvia, 2011). Other studies address the managerial role in relation to built-in paradoxes of multi-actor processes in collaborative governance (Purdy, 2012; Vangen \& Winchester, 2013; Vangen \& Huxham, 2011). The latter argue that the potential and challenges of managing collaboration are better understood in terms of management tensions and power relations. As such, it is not surprising that managing collaborative governance is not just applying a new concept to practice alongside other tasks. Since 'managing the tensions and paradoxes of these governance regimes has become the order of the day for public managers' (Pedersen \& Hartley, 2008: 328), the complications of practicing new roles alongside others are surprisingly under-explored.

This article studies the changing roles of public managers involved in developing collaborative governance in practice. Rather than identifying a new management concept, it is especially puzzled by the new role expected of managers; it questions the seemingly unproblematic role change implied in many studies to become facilitators of diverse stakeholders in collaboration. In addition to the aforementioned studies emphasizing tensions and power, I will draw on organizational discourse studies concerned with managerial identity in relation to discourse (Thomas \& Davies, 2005). This adds concepts to study role changes and conflicts as identity constructions constituted by positioning. This leads to the question: how are public managers positioned to manage collaborative governance and with which challenges? The study is based on ethnographic data from collaborative governance practices in the Danish daycare sector, in which stakeholder involvement of public managers, politicians, daycare managers, daycare teachers, and citizens (children and parents) is used to develop quality management.

The findings show that when managers construct new managerial roles to facilitate collaborative governance, they struggle to change accordingly. But through their efforts they create agency to steer collaborative outcomes. However, as they are not just changing from one role to the other, they also struggle with the contradictions of multiple roles associated with various public management discourses. As such the challenges of managing collaborative governance do not just involve changing into a new role, but also positioning between multiple roles continuously. This article contributes by theorizing and unfolding such complications as identity struggles constituted through positioning. It offers an empirically grounded understanding of the challenges involved in constructing new and changing managerial roles in collaborative governance practices and associated public management discourses. This elucidates the tensions emerging from locally produced public management discourses by their effects on managers-namely the challenges of role change and role 'doubling.' It adds to existing studies of management tensions and discursive power in collaborative governance, by unfolding constitutive aspects of managerial roles and effects of emerging public management discourses. 
In the following section I address collaborative governance studies concerned with complexity and the implications of the new managerial role. Next, I present the organizational discourse studies on managerial identity and the analytical concepts used. Following this, the empirical cases are presented along with research methods and analysis. Then the findings are unfolded, which leads to a discussion in relation to extant literature.

\section{The new managerial role in collaborative governance and its challenges}

As different forms of collaborative governance are developing in relation to different welfare areas, multiple definitions appear in the literature (O'Leary \& Vij, 2012; Osborne, 2009; Purdy, 2012; Vangen, Hayes \& Cornforth, 2014). This article adopts a broad definition as:

\footnotetext{
Public management and policy making that: 'engage people constructively across the boundaries of public agencies, levels of government, and/or the public, private and civic spheres in order to carry out a public purpose that could not otherwise be accomplished. (Emerson, Nabatchi \& Balough, 2011: 2)
}

As such, this kind of governance is contrasted to other public management discourses concerned with hierarchical and market-incentive models of public policy or service innovation, especially that of NPM (Ansell \& Torfing, 2014; Hartley, 2005; Osborne, 2009). Consequently, collaborative governance involves great changes to public management actors' working life in order to engage stakeholders constructively despite different positions and perspectives on the issues in question-the challenges of which are ascribed to the new role of the manager (O'Leary \& Vij, 2012; Silvia, 2011).

Accordingly, the literature develops models that depict the complexity of this form of governance as well as management concepts to deal with such challenges (Ansell \& Gash, 2008; Johnston, Hicks, Nan \& Auer, 2010; Silvia, 2011; Weber \& Khademian, 2008). With notions such as facilitators and capacity-builders, the new managerial role is often contrasted to the 'command and control' and 'hire and fire' practices related to NPM discourses (Ferlie, Hartley \& Martin, 2003: 10; Silvia, 2011: 67). The manager is still considered central, but expected to change:

\footnotetext{
The point is not that managers are unimportant. Complexity typically makes leadership more important, and this leadership often comes from managers. However, managers operate differently from the ways anticipated by NPM. Their role is not narrowly to implement and manage competitive contracting or performance measurement. Instead, they have an important role in building collaboration among multiple stakeholders. (Ansell \& Torfing, 2014: 10)
}

While such studies argue to conceptualize the new role of managers in collaborative governance to improve theory and practice (Johnston, Hicks, Nan \& Auer, 2010; Silvia, 2011; Weber \& Khademian, 2008), others argue to elucidate the socially dynamic tensions and powers (Purdy, 2012; Vangen \& Winchester, 2013). Instead of offering readyto-use concepts for more 'people-oriented behaviors' (Silvia, 2011: 67), the latter studies argue to theorize and elucidate the social dynamics that evolve within and between 
collaborative governance events to better understand the complexity and paradoxes of managing such. With the notion of management tensions, Vangen and Winchester (2013) conceptualize the managerial challenges following a 'culture paradox'-when the diversity of stakeholders may cause both successes and conflicts in the social dynamics of collaboration. They show how the multiplicity of actors working with contradicting and even competing discourses complicates the managers' practices of facilitating collaboration. They argue that managers work through tensions, and so they propose to integrate rather than solve the challenges of diverse actors in interorganizational processes.

Another aspect critical to managers working with collaborative governance is power. Contrary to the forms of power connected to practices of hierarchy and market-incentives associated with NPM, this form of governance produces power through social dynamics in networks. This involves giving stakeholders the right to speak and the opportunity to affect issues of local welfare policy and management (Karlsen \& Villadsen, 2008; Purdy, 2012). This means that power induced through managerial hierarchy is not seen as dominating; rather power relations produced by social dynamics are theorized as central to collaborative governance and therefore critical matters to managers. Especially Purdy (2012) conceptualizes this form of power and the following managerial challenges. She describes three arenas of power, namely formal authority, resources, and discursive legitimacy, which influence the management of participants, process design, and content. Specifically, discursive power is stressed as critical to managers:

The elements of power in a collaborative governance process are often intertwined, as when a participant uses discursive power to challenge the authority of the convener to establish the process design. Such a move might result in a negotiation that changes the structures of meetings, participation, or the availability of resources to participants. (Purdy, 2012: 416)

By conceptualizing the socially dynamic and situated aspects of power, she argues that this challenges managers in ongoing negotiations of processes and outcomes. In this regard, it is important to stress that 'power' is not considered a possession or a static role of authority secured by a hierarchical chain of command (Karlsen \& Villadsen, 2008; Purdy, 2012; Thomas, Sargent, \& Hardy, 2011). Rather, the power theorized as critical to collaborative governance works through social dynamics, as Purdy (2012) argues and stresses discourse as a constitutive force. This challenges the managers; they cannot rely on their familiar role of authority. Rather a new role of facilitation is needed to work through socially dynamic tensions and discursive powers (Karlsen \& Villadsen, 2008; Purdy, 2012; Vangen \& Winchester, 2013).

Echoing these studies, this article is particularly puzzled by the problematics of constructing new roles when changing to become a facilitating manager alongside other roles. These constitutive processes and the challenges involved during changes in role are surprisingly under-explored. I will add that by approaching the role changes as struggles of identity and agency produced through public management discourses and associated practices, we may understand the challenges of role changes with sensitivity to their constitution. This is crucial to the study of new forms of governance-not because managers necessarily steer such processes, but rather because managers themselves are embedded in social dynamics that complicate the role changes and affects the local governance forms. 


\section{Studying challenges of roles: subjectification and the positioning of managers}

Instead of identifying a new managerial concept this article adds theorizing and unpacking of the discursive constructions through which managers struggle with creating new and changing roles. To do so I draw on organizational discourse studies of managerial identity in relation to discourses of NPM and collaboration. In the following I present the theoretical framework of identity as discursively constructed through subjectification and the analytical concept of positioning to study the manager's changing roles.

Although managers are usually seen as privileged actors whose role is to manage others' work, the idea of a fixed role with a core identity and autonomous agency is contested in organizational discourse studies (Ainsworth, Grant, \& Iedema, 2009; Alvesson, 2010; Bergström \& Knights, 2006; Thomas \& Davies, 2005). Following this the role of managers - their identity and agency-is theorized as discursively constructed. Such understanding is concerned with exploring power relations of discourse, identity, and agency, but the studies vary in the degree of determinism between discourse and subjects (Alvesson, 2010). This article echoes studies inspired by Foucault and his theorizing of subjectification as the construction of identity and agency (Bergström \& Knights, 2006; Davies, 2006; Foucault, 1994: 326-348; Thomas \& Davies, 2005). Subjectification is a process through which actors are simultaneously subjected to certain discursively constructed identity markers and subject positions, as well as empowered with the agency to act within the tensions between multiple discourses. This involves power relations that both subject actors to identify with the subject positions available in discourse, and enable agency to enact by and upon discourse. It occurs in discursive negotiations and struggles that produce situated meaning and identity constructions. As such actors are not seen as mere discursive effects but also as discursive producers.

Subjectification involves discursive power production that is generated through everyday enactments of textual and social practices that form subject positions and become constitutive to identity and agency (Foucault, 1994; Thomas \& Davies, 2005). Discourse in this sense means: 'collections of interrelated texts and practices that "systematically form the object of which they speak"' (Foucault, cited by Hardy \& Thomas, 2014: 324). In this regard discourse is taken to be produced through a variety of communications including written texts, interactions, artifacts, symbols, pictures, etc. (Philips \& Oswick, 2012), with which organizational actors construct identity and agency. Thus the interest is in the discursive production of subject positions-their enablement and restraints-by which managerial identity takes form and creates the changing roles of the manager.

This understanding shifts the analytical attention to the discursive formation and struggle over meanings that demarcate and negotiate particular subject positions made available in communication concerning the role of the manager-their positioning. Positioning thus becomes the analytical focus (Davies, 2006; Davies \& Harré, 1990). It is a discursive practice entailing both subjection and agency, and as such it refers to the changing practices by which communication forms clusters of normative meanings, through which managers identify and condition themselves, but also become agentic. Analyzing positioning elucidates how the role of managers in collaborative governance is discursively constructed, negotiated, and, possibly, changed. Thereby the focus is dislocated from the role as fixed with a core identity to the ongoing positioning in subjectification 
processes. This elucidates struggles of identity and agency, through which managers create new roles and role changes in relation to the constraints and enablement of various public management discourses. Also, it can unpack how the managers affect the constitution of new forms of governance locally.

This approach is useful because it pays particular attention to the emerging identity and agency, which is relevant in relation to elucidating discursive aspects of the new role of managers as facilitators identified in the collaborative governance literature. It entails analyzing the ways in which managers are constructed through discourse; how they categorize themselves and others, how they are created in texts, including what is included/excluded in these subject positions, how they become value-laden and with which effects on the agency of those subject positions (Davies \& Harré, 1990). Furthermore, it involves studying how positioning entails identification, subscription, or also resistance to the subject positions-how a role may be taken or changed (Thomas \& Davies, 2005). In other words, how managers talk about themselves and others, how they and their work is described in relation to collaborative governance in documents, and how they act prior to and during collaborations, as well as how they are positioned bodily and spatially.

\section{Cases of collaborative governance in the daycare sector}

This article is based on a qualitative study of collaborative governance practices in the welfare area of daycare in two Danish municipalities from 2010 to 2014 (Hviid \& Plotnikof, 2012, 2013). The daycare departments in the municipalities are interesting cases as they formed a partnership with the Danish Union of Early Childhood and Youth Educators in 2010 to develop new forms of quality management through collaborative governance. The daycare sector is governed by local daycare departments accounting to a head of division and a political committee in the local municipalities. The municipalities in this study are medium sized (ca. 45,000 citizens) and the daycare departments govern a number of local daycare centers and staff of daycare managers and teachers. The daycare departments typically consist of a public management team, including a department head and several managerial consultants with both administrative and educational responsibilities. The actors of the management team have varying tasks; the head has all official personnel responsibility, but the consultants often perform both administrative and educational tasks, including personnel education, evaluation, quality reports, and inspections. In the present case study the whole management team held the managerial responsibility in relation to their collaborative governance practices, and the managerial consultants often were the primary facilitators and organizers of local events. Therefore, I refer to all the actors in the management team as public managers, although their work includes different levels of responsibility.

Daycare is a central welfare area in Denmark, which is currently subject to modernization policies (Egelund, Hansen, Csonka, Jørgensen, Davidsen, Sloth \& Jacobsen, 2012). In the past decade daycare governance has already changed due to the enrollment of new quality management policies and practices such as education plans (quality reports) and quality inspections-the effects of which stakeholders discuss as standardization and control associated with NPM (Hviid \& Lima, 2011; Plum, 2012). In response, new attempts to modernize daycare governance and its quality 
management have appeared (EVA, 2013), including the cases in this study. As such, efforts of collaborative governance within the educational sector relate to discussions of public management discourses such as NPM and NPG to enable public policy innovation (Ansell \& Torfing, 2014; Bason, 2010; Sørensen \& Torfing, 2011). One of the problems expressed in the present cases concerned the existing quality management reports and their one-way communication, which were considered 'meaningless' by politicians, daycare managers, and teachers. The 'different languages' of these stakeholders were seen as problematic, because public managers had to 'translate' between stakeholders. Consequently the stakeholders expressed the need to develop new quality management methods by collaboration.

From 2010 to 2012 various collaborative governance processes emerged in laboratory workshops in the two daycare departments, involving stakeholders from across the daycare sector to collaborate in knowledge sharing, idea creation and multi-actor discussions. Some laboratories included various stakeholders, e.g., public managers, politicians, daycare managers, teachers, parents, and children from four daycare centers, while others consisted of specific groups, e.g., public managers. The laboratories concerned both existing and potential quality management methods to daycare, and their challenges and possibilities were explored. In each municipality around 10 interorganizational workshops, each with around 20 stakeholders, were conducted. Between these events the management teams conducted workshops at the city halls, as did daycare managers and teachers in daycare centers. In 2013 it was politically decided that the collaborations about quality management should continue. This resulted in yearly daycare 'marketplaces' and 'dialogic inspections' throughout 2013-2014. At the daycare marketplace all stakeholders (3-400 people) met local daycare managers and teachers, who presented and discussed daycare quality with other stakeholders-instead of accounting in reports. Through this, quality accounts include videos, pictures, narratives, and dialogues, and this is seen as a better form of quality management due to the knowledge sharing among stakeholders.

\section{Methods and analysis}

I studied these collaborative governance practices over a period of 4 years with varying intensity and methods. ${ }^{1}$ The method design aimed at producing rich data and was inspired by organizational discourse approaches and ethnography (Fairhurst \& Grant, 2010; Grant \& Marshak, 2011; Yebema, Yanow, Wels \& Kamsteeg, 2009). This involved varying ethnographic methods to study the communication, practices, and materials relating to collaborative governance and its managers. The data-set includes field notes, photos, video and audio recording from participant observations in collaborative governance practices at city halls and daycare centers, and from single and group interviews (unstructured) with managers, daycare managers, and teachers, and a number of organizational documents such as participant-written reflection notes, e-mails, etc. The methods used for data collection were critically considered during data analysis and along the way analytical points were discussed with participants to allow them to nuance these.

To manage the data I produced an event history database showing when and where the data was collected, what activity and who participated, and my notions of initial analytical curiosity (Hardy \& Thomas, 2014). During the initial coding I noted a 
recurring empirical concern regarding managers' roles and decided to undertake a systematic analysis. A preliminary analysis across the data showed communication about the role of managers in multiple data sources, but this was also explicit in interviews (12 single/group interviews with public managers and daycare managers), managerial workshops and meetings (17 events with public managers), and in some organizational documents ( 1 partnership newsletter, 2 meeting minutes, 1 article) that I selected for further analysis. However, in order to include implicit or nonlinguistic communication of the role of managers, I also selected data sources from interorganizational laboratory workshops and collaborative governance conferences (public managers and stakeholders like politicians, daycare staff, and citizens) to analyze the positioning of the managers during this type of work.

I analyzed the data sources in multiple movements to construct and qualify analytical patterns (James, 2012) concerning roles in the positioning of managers. This included an 'open' analysis through which I followed empirical voices and practices concerning managerial roles in their collaborative governance practices. This amounted to a cluster on positioning acts in terms of, e.g., 'old vs. new roles', 'changing from the translator to the facilitator', the 'middle position in a field of tensions', 'letting go of managing'. However, these were often accompanied by communication forming a cluster relating to the organizing of 'public management' in different terms, such as 'hierarchy', 'top-bottom', 'out there/in here', 'secretariat' 'direct communication between politicians and teachers', 'authentic dialogues and collaboration', 'knowledge sharing and innovation across the organization' that invoked discourses of NPM and NPG more or less explicitly. I then did numerous focused or 'closed' analyses to unfold and qualify the examination of these clusters in relation to studies on managing collaborative governance and to managerial identity in organizational discourse studies. These developed patterns of the positioning processes, which I reanalyzed by several critical iterations.

This amounted to a three-part analysis (see Table 1) of managers' positioning which shows (1) how a demand for a new role is created, (2) how this produces struggles of changing roles and multiple roles, and (3) how it enables a new agency to steer collaboration by specific forms of facilitation. The three parts elucidate interconnected aspects of the positioning, and the divisions are to mediate rather than to represent demarcated processes.

Table I Analytical findings

\begin{tabular}{|c|c|c|}
\hline Part & Discursive practices and positioning & Constitutive effects \\
\hline I & $\begin{array}{l}\text { Constructs a contrast between hierarchical } \\
\text { and collaborative forms of governance, } \\
\text { the latter is considered the better }\end{array}$ & $\begin{array}{l}\text { The managers are subjected to } \\
\text { demand for role change from } \\
\text { translator to facilitator }\end{array}$ \\
\hline 2 & $\begin{array}{l}\text { Construct the new role in positive terms, } \\
\text { but problematize its managerial changes } \\
\text { in terms of risks and hard work }\end{array}$ & $\begin{array}{l}\text { The managers struggle with } \\
\text { changing in order to practice } \\
\text { a new role alongside others }\end{array}$ \\
\hline 3 & $\begin{array}{l}\text { Construct an agency to steer collaborative } \\
\text { processes and outcomes }\end{array}$ & $\begin{array}{l}\text { The managers create empowered } \\
\text { agency despite their struggles } \\
\text { over multiple roles }\end{array}$ \\
\hline
\end{tabular}




\section{Findings}

In the following sections I unpack the findings to show the challenges involved for public managers to create new and change existing roles during practices of collaborative governance in relation to other public management discourses. The findings are outlined in three sections; the first part concerns how managers communicated collaborative governance as a solution to local problems-in this case quality management in daycare and in so doing constructed old and new roles. The second part highlights how the managers struggled to change identity and agency accordingly-and that they struggled with their multiple roles. The third part elucidates how, through their struggles, they enabled an agency to steer collaborative outcomes. Hence, the findings show the discursively constructed constitutive effects of managers' positioning within new and changing roles connected to multiple public management discourses.

\section{From old to new role: Positioning managers as facilitators}

In both municipalities the public managers constructed collaborative governance as a solution to local problems of quality management in daycare. In meetings and workshops this potential and its challenges were discussed and new quality management methods developed to enable 'better' communication regarding daycare quality between stakeholders such as politicians, daycare managers, teachers, and parents. 'Better' was voiced in contrast to the existing methods often referred to as quality control reports. But as the managers constructed collaborative governance as a solution-a demand for role change followed. In the next excerpt (newsletter, 2012) two department heads contrast quality management methods related to control with their local collaborative governance practices, and in so doing imply their old role:

Steven: Traditionally, daycare teachers account for their work in written reports, which the administration interprets before the politicians receive them. Some information disappears in this governing chain of command and a discrepancy emerges between what the politicians receive and what actually happens in daycare practices. In the collaborative laboratories we see a far more authentic communication about professional daycare. As administrators and politicians we were told, face to face, about theories, methods and results and we entered a dialogue that enlightened us about how to support good professional daycare practices. The alternative is that the staff describes this in writing, but it easily becomes another piece of paper on the desk.

Peter: Usually the changes start from the top or from the outside. Then it's the role of the administration to channel that to the daycare centers. Sometimes that works fine, but mostly it actually doesn't work. The collaborative governance practices turn the pyramid upside down. Here it's the daycare workers who create the knowledge that is brought to the political level.

In their talk the difference between the two governance practices was contrasted in terms of written reports and chain of command vs. authentic communication and turning the pyramid upside down. With such contrasts the potential for collaboration between 
stakeholders was stressed as the opposite of 'another piece of paper.' Steven argued that collaborative governance solves issues of discrepancy between daycare reality and the information politicians receive. In doing this he not only implied the potential of collaborative governance in positive terms, but also problematized the public managers' old role as interpreting written reports-because some information disappears in the governing chain of command. Peter problematized a top-down procedure and described the public managers' old role as a middle position that does not work. Thereby they positioned their old roles in a hierarchy as part of the problem. This construction of old and the new managerial roles was further unfolded:

Steven: As administrations our role will change from translating educational logics to political logics-instead we have to facilitate the dialogue between politicians, daycare centers, parents and children, and also other welfare services dealing with children. It's a new role that's in demand in today's governance.

When Steven positioned the management team in a new role to facilitate stakeholder collaboration, he constructed a demanded role change from translators to facilitators. He considered the new role better suited for current ways of governing. In their communication the managers expressed collaborative governance as the solution to problems related to hierarchical quality management practices of control. They constructed an old managerial role of translating information as part of the problem, as it produced discrepancy, and thereby a demand for change to the new role. Their positioning of the new role to facilitate stakeholder collaboration was contrasted to hierarchy and control in terms of paper work, and the former was signified as better, which made the demand for change more pressing. But as shown next the managers struggled with changing accordingly.

\section{Letting go of managing? Struggles of positioning}

During the managers' work with collaborative governance, the challenges of their new role became evident. The managers struggled over the meanings ascribed to the new role, as they sought to identify with it and create an agency to facilitate collaboration. In the following example (Interview, 2010) one of the department heads has just explained the potential of collaborative governance from his managerial position, but then he unfolds his struggles:

Steven: There are some potential risks here. I'd almost call it a short circuit of the managerial chain in the municipality, when a daycare manager gets direct access to the political arena. I think it's crucial to establish ground rules for this type of collaboration. The hierarchical system is sometimes nervous about breaking the hierarchical boundaries. It's a little too focused on the risks instead of the children and the wins of such endeavor. I think it is natural though, when it has to do with control. I would feel an uncertainty, if I experienced that a daycare manager and a political member of the committee are in dialogue without me. I'd think 'what the hell is she doing?' I really need to work on my trust here. It's the nervousness that prevents establishing direct access.

Steven unfolded problematics of collaborative governance in terms of the risk of direct access between stakeholders, and he explained that the hierarchical system was more focused on the risks of losing control than on the potential of collaboration. But in his 
explanation he also unpacked the reasoning in relation to his own role; he struggled with uncertainty and trust. He legitimized his struggles as a natural part of a hierarchical system concerned with control. In this positioning he subjected himself to the demand for changing roles, but he stressed the challenges that made him uncertain and would involve trust building. Similarly, the positioning of the other daycare department head showed that making changes according to the new role was not easy. In the following example he discussed with the management team how collaboration across stakeholders changed their practice (managerial workshop, 2011):

Peter: That thing I have to do with the daycare centers rather soon, right? Where I'm visiting three daycare centers to reduce their playground area, because we can't afford to maintain it-if I was a NPM manager, but now I've already self-glorified myself, right? But if so, I would have made my decision on a piece of paper and sent it out: "that's how it's gonna be!" But instead we collaborate and negotiate with local daycare managers. So, yeah, we are changing in effect of this attention [to collaborative governance] to avoid becoming an awful top-down management.

By positioning in opposition to a top-down management he subjected himself and his management team to the role change following collaborative governance and highlighted the agency it involved, namely collaborative communication and negotiations with other stakeholders, in this case daycare managers. However, by stressing this positioning as a self-glorification he also acknowledged that it is not easy to change into an ideal, even if it is something he himself invoked. But he is stressing that he is making the effort instead of making the decision on a piece of paper because he wanted to avoid that old role.

During the collaborative governance practices, the managers were also positioned by the other collaborative governance actors' interaction. The social dynamics of others during collaboration were referred to as critical matters, which the managers struggled with when changing roles. As such, they described risks and challenges of living up to the self-glorified role they positioned themselves in. The managerial challenges of the social dynamics emerging from the stakeholders' collaboration unfolded further in a conversation between two consultants, Ulf and Maria, and the department head, Peter (interview, May 2012):

Peter: It's hard work, right? Because the way it is now, eh-the political committee, as always, asks me. But they also go out there. You know, that's the fun part now, right? That's the new thing; we just have to live with, right? That they just-they aren't too snobbish to visit a daycare center and get a feeling of-what's the atmosphere there? So these kinds of things have happened. You know, I don't know what caused it. It may be the collaborative governance laboratories. You, you can write that.

Ulf: That nurtured them to do that; there's no doubt about that.

Peter: They're extremely interested.

Ulf: That voice out there, they are really focused on it—as an important voice. There's no doubt about it.

Peter: No. So they go out there. You know, that's anxiety provoking in an administration. 
The managers express that the emerging collaboration of the other stakeholders also affected their positioning; although they saw the collaboration as a sign of the success of collaborative governance, it also challenged their managerial identity and agency. They stressed the positive side by stating that the daycare centers were becoming important to the politicians. However, along came managerial challenges-the new situation in which politicians visited daycare centers without including public managers-which they saw as anxiety provoking. Thereby the politicians also positioned the managers in the new role; although they asked the head, they also acted independently. This implied a constrained agency in the new role of the managers; an unmanageability between collaborative governance actors, which the management teams found challenging. The managerial constraints of such unmanageability involved struggles of identity and agency during the managers' positioning, which were further expressed as the team discussed the biggest changes following collaborative governance:

Maria: I was thinking, you know, letting go of managing. I think that's rather crucial too, right? You know. I told you how I felt after my first [facilitation of a] laboratory, right? You know, and the frustration gives a tremendous experience, but you know saying: "how's it working, when I can't plan and when I don't know how the outcome will be?" Or I tried to plan it, but then it turned out differently, and I didn't really know what the bloody outcome was. It wasn't what I expected, and maybe I didn't want it to be that, but in the end that was where we ended, and that's the point, isn't it. You know saying: 'well all that management-that becomes so un-reflexive sometimes. We turn it around and we let go of managing and then we actually reflect a lot more, right?

Ulf: yes, and we get the opportunity to hold on to our intentions, and then they actually lead the way, instead of a predefined outcome.

Maria described the challenges of changing roles by emphasizing her difficulties with letting go of the old managerial role. She stressed the challenging unmanageability of not following a plan and not steering the outcome of collaboration. But although she struggled with these constraints of the new role, she constructed the frustration as a part of the change that allowed her to let go of managing — and in the talk the team highlighted a collaborative reflexivity as more important than the old managerial role. Through their troubles of changing roles and dealing with the frustration of unmanageability, the managers also constructed collaborative governance as worthwhile letting go of their old role for.

In sum, we have seen that although the managers constructed collaborative governance in positive terms as a solution to local problems of quality management related to NPM and their old roles-the changes implied did not follow easily. Rather they involved complicated positioning through which the managers struggled to construct identity and agency according to the new role and associated public management discourses alongside others relating to hierarchy and control. To the managers this involved constraints in the agency of the new role, and they struggled to change accordingly; Steven saw risks, Peter called it anxiety provoking, and Maria talked about the frustration of not following the plan. Altogether this complicated their role change from translators to facilitators, as it became evident that they were not just to change between roles, but rather to double their roles. The complications of positioning in a new role alongside others were expressed as contradicting demands (managerial meeting, June 2013): 
Maria: I've had to walk in two directions, because, I don't have politicians that are fully committed [to collaborative governance]. I deal with politicians that exactly also go in the opposite direction, and suddenly get the idea that [quality control] is also nice.

In such ways the managers' new facilitating role was also constrained by the interests and social dynamics of other participants, such as politicians. During the positioning they struggle with the unmanageability of the social dynamics in and between collaboration, by the way it is taken as both enabling and constraining them. On the one hand they glorify the new role and reflexivity of collaboration, on the other they struggle to let go of managing and leaving the hierarchical system of control behind.

As such, the analyses of the managers' positioning showed struggles over roles related to different discursive constructions of public management (control and hierarchy vs. direct communication and collaboration) through the way this affected their identity and agency. Their positioning showed situated constructions of multiple roles and the complications of role changes in struggles over identity and agency in relation to other governance actors and other public management discourses. But these struggles also generate creative ways of positioning to gain particular forms of agency, which is elucidated next.

\section{Empowering the facilitating manager}

As demonstrated, the managers struggled to change roles and in their positioning between roles and dealing with multiple roles they were challenged by the unmanageable social dynamics of collaborative governance. But in their work to deal with the constraints of the new role of facilitation, they also created an agency that empowered them to steer. In the following conversation (group interview, 2012) between the department head, Steven, and the public manager, Britt, they say:

Steven: If I rewind to the time when I problematized what the democratic risk was in this, right? You know, can we live with it or should we avoid it - if it becomes an exclusive access for a group of people to affect the political agenda via direct communication, right? You know, it's in this regard that I, as a public manager, have a really, really important role. Not so much as a translator but to be the one who brings the collaboration into a meta-perspective, right? And try to extract the essence and say: 'alright, what does this tell us? What we just heard, what might that tell us about the daycare area? What might it tell us about the next relevant step to governing and set direction for the development of the area, right?

Britt: And that's a really important role of facilitating, right? You know, you're creating those meta-perspectives. You provide people with a forum for reflection based on those grounds. You know, it's a really important role and a different role-than just being a translator.

The managers referred to the risk of access to affect political agendas by which they positioned their new role as being more important than the old one of just translating. Through this, they identified with becoming facilitators, but they empowered this identity with a certain agency legitimized by risks. This agency includes steering the collaboration with meta-perspectives, plus summarizing their essence and defining their 
substance, with which to set direction in the daycare area. As such, the managers constructed agency to facilitate by steering the collaborative outcome which was legitimized by the risks of the social dynamics of stakeholders that could affect political agendas. This required a managerial agency that facilitated collaborative forums and communicating its relevance to decision making and setting direction.

This steering agency of the facilitator role was enacted through the managers' positioning during a multi-actor collaboration (April 2012). In order to include a child's perspective on daycare quality, this collaborative governance workshop took place in a daycare center (as opposed to its typical location at the city hall). It included public managers, politicians, daycare managers, teachers and children ( 24 people). Before the children arrived, the facilitating manager handed out questions to direct the participants' attention: 'What knowledge on daycare quality do you gain from listening from your position in the daycare field?' This framed the process and the outcomes which the managers afterward saw as 'meta-perspectives' to steer the further decision-making. A field note describes that:

Seven children (around 4-5 years old) enter with a teacher and gather around a table located in the middle of the room. We all quiet down and stand around the children, not in a circle but so that everybody can see the table, they are sitting around. On the table pictures are lying around showing the children in a forest. The teacher and children start talking about a daytrip into the woods; their experiences with each other, the animals, the nature and the physical activities they did there. Twenty-four people are crowded around them with note pads labeled e.g. 'teacher', 'daycare manager', 'administrator' or 'politician' (indicating their formal role in the collaboration). The children do not appear to pay any attention to them, but the adults standing around are very attentive to the children; they write eagerly on their pads and have smiling faces.

After 25 minutes the children left, and a two-hour workshop began in which they discussed their notes and answers to the question asked by the facilitating manager on how they could use it for quality accounting. Afterward the management team produced a document of 'meta-perspectives' defining the knowledge needs of politicians and administrators, and the daycare staff's interest in accounting daycare quality. This document was used to show the result of their collaborations to the political committee and it was also used for the organization of new collaborative governance events called daycare marketplaces. Thereby we see how managers created agency during their positioning and struggles over roles, which in this case produced a facilitating agency that allowed them to steer the framing of a process and the definitions of the outcomes, which effects the future ways of organizing daycare governance.

In their positioning the managers refer to collaboration and control as discursive resources by which they construct collaborative governance as solutions to local problems of quality management associated with hierarchy and NPM discourses. In so doing, they position themselves through discursive tensions of unmanageability and manageability, by which they move between the constraints and enablement of their multiple roles. The managers' positioning therefore subjects them to demands of role changes in discursive tensions of, e.g., collaborative governance and NPM causing struggles of identity, yet simultaneously empowers them with agency to form a certain kind of facilitation-among other roles. As demonstrated, it is definitely not an easy solution to pursue neither collaborative governance nor the role changes discursively implied. However, the efforts to 
undertake such endeavors are nevertheless seen by the managers as a worthwhile struggle in the present study-although it presents new challenges to walk in two directions.

\section{Discussion}

The findings of the case study on managers' positioning firstly elucidated how managers communicated collaborative governance in relation to other public management discourses and the new managerial role they were subjected to. They constructed collaborative governance as the solution to local problems of existing hierarchical organizing and control, including their related role of translation. Thereby they produced a demanded role change to become facilitators. The second part showed that they struggled, however, to change accordingly due to the constraints of the new role in relation to other managerial tasks and actors. In considering this, the managers described risks and frustrations connected to the unmanageable social dynamics emerging through stakeholder collaboration. The last part of the analysis explored how they, through these struggles, also created a particular agency of facilitation; legitimized by the unmanageable social dynamics of collaboration they enabled their facilitation to steer collaborative outcomes. As such, the findings show the complicated constitutive processes and effects of locally constructed public management roles and associated discourses through positioning. This unfolds the struggles of identity and agency involved when undertaking a new role as well as changing between multiple roles associated with different discourses. This suggests that we consider role changes not as linear processes or static end-states, but rather as situated effects of ongoing positioning, which change in relation to locally emerging discourses.

The findings offer empirically grounded understandings of the challenges involved in constructing new and changing managerial roles during collaborative governance by unfolding the discursive tensions associated with NPM and NPG and their managerial effects, which corresponds with current collaborative governance studies (Ansell \& Torfing, 2014). Although these findings are case-specific, they contribute to the literature on the new managerial role. Others (e.g., Silvia, 2011; Vangen \& Winchester, 2013; Weber \& Khademian, 2008) have identified this new role as the facilitator and discuss the managerial challenges implied when bringing together diverse actors in collaboration: a tricky process demanding managers to facilitate stakeholders such as politicians, welfare workers, citizens, etc. to become partners in delivering inputs and producing output. Identifying new roles are useful and thinking about the challenges implied as working through tensions (Vangen \& Winchester, 2013) is valuable to highlight the complexity involved in managing this kind of governance practice. However, the present study shows that roles are not static or powerful per se, but subject to ongoing struggles over meaning and discursive constructions. Therefore, in addition to identifying new roles and tensions this article elucidates the complications of changing roles and working through tensions. It thus stresses a need to further consider the problematic of multiple co-existing roles (Pedersen \& Hartley, 2008), and that the concept of role is insufficient in this regard.

As suggested, the theorizing of subjectification and the concept of positioning is useful to explore constitutive aspects of public management roles and associated discourses produced through managers' identity work (Thomas \& Davies, 2005). This involves addressing the positioning of actors in their identity construction with regard to more or less preferred roles and their enablement of specific agency, which form particular local 
versions of collaborative governance. Revisiting the notion of management tensions (Vangen \& Winchester, 2013), the present study suggests that, in addition to understanding such challenges as working through certain tensions, we must unpack emerging discursive tensions by studying managerial positioning acts. This elucidates the challenges that arise with regard to different roles associated with different forms of public management and their effects in local practice. In extension to identifying specific management tensions (Vangen \& Winchester, 2013), this article has shown the challenges emerging from multiple roles and the discursive tensions between these.

Although the change to facilitation may seem as a loss of authority and managerial power, the facilitating manager can produce power by bringing certain actors together, frame processes, topics and outcomes (Karlsen \& Villadsen, 2008). Purdy (2012), in particular, conceptualizes power relations, in which discursive power is theorized to produce legitimacy and elucidate the negotiation of managerial power between actors within collaborations. In extension, the present study elucidates negotiations of power to steer not just within collaboration and between collaborative actors, but also the struggles to empower managerial agency prior to, and in between, collaboration. The effects of this on managers include that they steer through their facilitation, as the present study demonstrated. Although the findings show how the management teams struggled over the meanings of the new role and letting go of managing, they also empowered the facilitating manager with agency to steer collaborative governance outcomes. This indicates that power relations are not just produced and negotiated within collaborations, but also prior to, and between, as managers position themselves and empower agency to facilitate in certain ways. Furthermore, this can also show the generative potential of discursive tensions, as demonstrated in the findings on the agency produced to steer collaboration.

Despite the unmanageable social dynamics of collaboration and the tensions that managers work through when practicing their new role, a facilitating manager can steer and set directions of a welfare area, but the power relations involved in enabling this kind of governance are negotiable in and between collaborations in tensions of multiple role constructions and associated public management discourses. These tensions and the power relations working through such are invoking competing ideals of NPM and NPG, which may co-exist, but also challenge managers as they position in struggles over roles in relation to other actors within and between collaborations and other public management tasks. Because of this, further studies of constitutive aspects and discourse are critical, both concerning this form of governance in general and, more specifically, concerning managerial challenges and the generative potential of their struggles with such.

\section{Conclusion}

This article has explored the changing role of public managers in collaborative governance by theorizing and unfolding managers' positioning. This redirects the focus from specific roles to their constitution. The findings of a case study of collaborative governance in the Danish daycare sector demonstrated how managers construct old and new roles through their positioning in tensions of various public management discourses related to NPM and NPG, and how they struggle with changing accordingly, from translators to facilitators. Nonetheless, the findings also unpacked how managers empower the new role with agency to facilitate in certain ways, which, in this case, allow them to

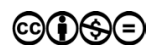


steer the framing and outcome of collaboration. As such, the findings suggest that public managers are struggling to position themselves as facilitators alongside other roles, but that they in effect are empowered to define certain agency locally. This proposes that we consider role changes not as static end-states, but rather as situated effects of positioning through struggles over identity and agency.

The study unpacks the complicated constitutive aspects of competing public management discourses and related practices by which managers position themselves between multiple roles and generate particular agency. This offers an empirically grounded understanding of the challenges of role change and their effects on managers created during the struggles of identity and agency relating to collaborative governance alongside other public management practices and associated discourses. Thus, in addition to conceptualizing new managerial roles and their challenges in terms of management tensions between various actors in collaborative governance (Silvia, 2011; Vangen \& Winchester, 2013) and in terms of discursive power as legitimacy (Purdy, 2012), this study expands the scope of managerial roles and challenges with its theorizing of subjectification and positioning. The exploration of constitutive processes and effects during positioning strengthens the understanding of the challenges of managerial identity and agency produced through tensions between multiple public management discourses and related practices to undertake new roles. Although these constitutive processes and effects are complex, conceptualizing and elucidating them enables us to see new facets of this form of governance.

Managing collaborative governance in practice is not only about learning a new concept to facilitate tricky multi-actor processes and thus deal with the social dynamics within collaborations. Although these are central aspects, a precondition is the discursive struggles over roles: the identity constructions that enable particular agency of facilitation and constitute local versions of this kind of governance. The exploration of this shows both discursive restrains and enablement emerging from ideals of NPM and NPG. Approaching related issues of, e.g., negotiating the organizational design of collaboration from a discourse perspective is worthwhile to advance. This could help us address the complex communication and its constitutive aspects crucial in this kind of governance further. Such a move fertilizes insights from studies on collaborative governance and organizational discourse further-a move this article contributes to.

\section{Acknowledgments}

I would like to thank Associate Professor Pernille Hviid, University of Copenhagen for the reflections and discussions we shared during fieldwork.

\section{References}

Ainsworth, S., Grant, D., \& Iedema, R. (2009) 'Keeping things moving: space and the construction of middle management identity in a post-NPM organization', Discourse \& Communication 3(1): 5-25. doi: http://dx.doi.org/10.1177/1750481308098762.

Alvesson, M. (2010) 'Self-doubters, strugglers, storytellers, surfers and others: Images of self-identities in organization studies', Human Relations, 1-25. doi: http://dx.doi. org/10.1177/0018726709350372. 
Ansell, C. \& Gash, A. (2008) 'Collaborative governance in theory and practice', Journal of Public Administration Research and Theory 18(4): 543-571. doi: http://dx.doi. org/10.1093/jopart/mum032.

Ansell, C. \& Torfing, J. (2014) Public Innovation through Collaboration and Design. New York: Routledge Publishing.

Bason, C. (2010) Leading Public Sector Innovation: Co-creating for a Better Society. London: Policy Press.

Bergström, O. \& Knights, D. (2006) 'Organizational discourse and subjectivity: Subjectification during processes of recruitment', Human Relations 59(3): 351-377. doi: http:// dx.doi.org/10.1177/0018726706064179.

Bryson, J.M., Crosby, B.C., \& Stone, M.D. (2015) 'Designing and implementing cross-sector collaborations: Needed and challenging', Public Administration Review 75(5): 647-663. doi: http://dx.doi.org/10.1111/puar.12432.

Christensen, T. \& Lægreid, P. (2011) 'Complexity and hybrid public administrationTheoretical and empirical challenges', Public Organization Review 11(4): 407-423. Doi: http://dx.doi.org/10.1007/s11115-010-0141-4.

Davies, B. (2006) 'Subjectification: The relevance of Butler's analysis for education', British Journal of Sociology of Education 27(4): 425-438. doi: http://dx.doi. org/10.1080/01425690600802907.

Davies, B. \& Harré, R. (1990) 'Positioning: The discursive production of selves', Journal for the Theory of Social Behavior. doi: http://dx.doi.org/10.1111/j.1468-5914.1990. tb00174.x.

Egelund, M. Hansen, O.H., Csonka, A. Jørgensen, K. Davidsen, I. Sloth, L. Jacobsen, L.J. (2012) Baggrundsrapport fra Task Force om Fremtidens Dagtilbud. [Background report from the Task Force on the Day-care of the Future]. Research Report. Ministry of Children and youth. Denmark.

Emerson, K., Nabatchi, T., \& Balough, S. (2011) 'An integrative framework for collaborative governance', Journal of Public Administration Research and Theory 22(1): 1-29. doi: http://dx.doi.org/10.1093/jopart/mur011.

Fairhurst, G.T \& Grant, D. (2010) 'The social construction of leadership: A sailing guide', Management Communication Quarterly 24(2): 171-210. doi: http://dx.doi. org/10.1177/0893318909359697.

Ferlie, E., Hartley, J., \& Martin, S. (2003) 'Changing public service organizations: Current perspectives and future prospects', British Journal of Management 14: 1-14. doi: http:// dx.doi.org/10.1111/j.1467-8551.2003.00389.x.

Foucault, M. (1994) Power Vol. 3, Essential Works of Foucault 1954-1984. London: Editions Gallimard.

Grant, D. \& Marshak, R.J. (2011) 'Toward a discourse-centered understanding of organizational change', Journal of Applied Behavioral Science 47(2): 204-235. doi: http://dx.doi. org/10.1177/0021886310 397612 .

Hardy, C. \& Thomas, R. (2014) 'Strategy, discourse and practice: The intensification of power', Journal of Management Studies 51(2): 320-348. doi: http://dx.doi.org/10.1111/ joms.12005.

Hartley, J. (2005) 'Innovation in governance and public services: Past and present', Public Money \& Management 25(1): 27-34.

Hviid, P. \& Lima, C. (2011) 'Pædagogik, Evaluering og Evaluerings-ubehag' [Pedagogics, evaluation and evaluation-discomfort], Pcedagogiks Psykologisk Tidsskrift 48(2): 103-120.

Hviid, P. \& Plotnikof, M. (2012) Nye Muligheder for Samarbejde I Styring og Organisering af Dagtilbud? En forskningsberetning om mangestemmige resultater fra laboratorier. [New possibilities for collaboration in governing and organizing the daycare sector? A 
research tale about plurivocal results from laboratories], Research report, Copenhagen Business School, Denmark.

Hviid, P. \& Plotnikof, M. (2013) 'Styringslaboratoriet: Eksplorativt samarbejde om "meningsfulde" organisatoriske forandringer-Erindringsværkstedet som eksempel' [Governance laboratories: Exploratory collaboration on "meaningful" organizational changes - the case of a memory workshop], Økonomistyring og Informatik 28(4): $387-420$.

James, A. (2012) 'Seeking the analytic imagination: Reflections on the process of interpreting qualitative data', Qualitative Research 13(5): 562-577. doi: http://dx.doi.org/10.1177 11468794112446108.

Johnston, E.W., Hicks, D., Nan, N., \& Auer, J.C. (2010) 'Managing the inclusion process in collaborative governance', Journal of Public Administration Research and Theory 21: 699-721. doi: http://dx.doi.org/10.1093/jopart/muq045.

Karlsen, M.P. \& Villadsen, K. (2008) 'Who should do the talking? The proliferation of dialogue as governmental technology', Culture and Organization 14(4): 345-363. doi: http://dx.doi.org/10.1080/14759550802489680.

O'Leary, R. \& Vij, N. (2012) 'Collaborative public management: Where have we been and where are we going?', The American Review of Public Administration 42(5): 507-522. doi: http://dx.doi.org/10.1177/0275074012445780.

Osborne, S.P. (2009) The New Public Governance? Emerging Perspectives on the Theory and Practice of Public Governance. New York: Routledge.

Pedersen, D. \& Hartley, J. (2008) 'The changing context of public leadership and management: Implications for roles and dynamics', International Journal of Public Sector Management 21(4): 327-339. doi: http://dx.doi.org/10.1108/09513550810880214.

Philips, N. \& Oswick, C. (2012) 'Organizational discourse: Domains, debates, and directions', The Academy of Management Annals 6(1): 435-481. doi: http://dx.doi.org/10.10 80/19416520.2012.681558.

Plum, M. (2012) 'Humanism, administration and education: The demand of documentation and the production of a new pedagogical desire', Journal of Education Policy 27(4): 491-507. doi: http://dx.doi.org/10.1080/02680939.2011.640944.

Purdy, J.M. (2012) 'A framework for assessing power in collaborative governance processes', Public Administration Review 49(3): 675-689. doi: http://dx.doi.org/10.111/j.15406210.2012.02525.x.

Silvia, C. (2011) 'Collaborative governance concepts for successful network leadership', State and Local Government Review 43(1): 66-71. doi: http://dx.doi. org/10.1177/0160323X11400211.

Sørensen, E. \& Torfing, J. (2011) 'Enhancing collaborative innovation in the public sector, Administration of Society 43(8): 842-868. doi: http://dx.doi.org/10.1177/ 0095399711418768.

Thomas, R. \& Davies, A. (2005) 'Theorizing the micro-politics of resistance: New public management and managerial identities in the UK public services', Organization Studies 28(5): 683-706. doi: http://dx.doi.org/10.1177/0170840605051821.

Thomas, R., Sargent, L.D. \& Hardy, C. (2011) 'Managing organizational change: Negotiating meaning and power-resistance relations', Organization Science 22(1): 22-41. doi: http://dx.doi.org/10.1287/orsc.1090.0520.

Vangen, S. \& Huxham, C. (2011) 'The tangled web: Unraveling the principle of common goals in collaborations', Journal of Public Administration Research and Theory 22: 731760. doi: http://dx.doi.org/10.10 93/jopart/mur065.

Vangen, S. \& Winchester, N. (2013) 'Managing cultural diversity in collaborations', Public Management Review. 16(5): 686-707. doi: http://dx.doi.org/10.1080/14719 037.2012.743579. 
Vangen, S., Hayes, J.P., \& Cornforth, C. (2014) 'Governing cross-sector, inter-organizational collaborations', Public Management Review. doi: http://dx.doi.org/10.1080/14719037.2 014.903658 .

Weber, P. \& Khademian, A.M. (2008) 'Wicked problems, knowledge challenges, and collaborative capacity builders in network settings', Public Administration Review 68(2): 334-349.

Yebema, S., Yanow, D., Wels, H., \& Kamsteeg, F. (2009) Organizational Ethnography: Studying the Complexity of Everyday Life. London: Sage Publications.

\section{Website}

EVA (2013) http://eva.dk/publications/narratives-and-evaluation-communities-concerningchildren2019s-language-development

\section{End notes}

${ }^{1}$ Part of the fieldwork was conducted in collaboration with Associate Professor Pernille Hviid, University of Copenhagen, and Professor Preben Melander, Copenhagen Business School. 